\title{
Straightforward Case of Dental Implant in General Dentistry
}

\author{
Aji P. Tjikman \\ General Practitioner, Mampang Prapatan, Jakarta Selatan 12790, Indonesia \\ Correspondence e-mail to: aji_tjikman@yahoo.com
}

\begin{abstract}
Dental implant has become a fast developing and dynamic field in dental practice. It is acknowledged as a predictable treatment modality with high clinical success rates. Conventional fixed prostheses are no longer considered to be the first choice treatment for replacing a missing tooth. Despite the increasing number of patients requesting dental implant treatments, there are only some clinicians who are offering implant therapy in their daily practice. The International Team for Implantology described a straightforward case as a simple case such as implant placements in adequate soft and hard tissue conditions and single-tooth restorations in a non-aesthetic zone. A review of the current literature discussed the implementation of implant dentistry in universities worldwide into their curriculum for both undergraduate and postgraduate programs in general dentistry. The European consensus in implant dentistry education concluded that it is desirable to include the surgical technique for implant placement for straightforward cases into the dental curriculum. The levels and limitations to which the various aspects of implant dentistry and related skills are to be taught are determined by the academic community. This review aimed at promoting awareness amongst dental practitioners and institutions in Indonesia of the shifting treatment paradigm in the management of a missing tooth. Hence clinicians will be able to include implant dentistry in the treatment planning of their patients and also undertake a significant part in the execution of such treatments.
\end{abstract}

\begin{abstract}
ABSTRAK
Kasus implan sederhana dalam bidang kedokteran gigi umum. Implan kedokteran gigi telah menjadi bidang yang berkembang cepat dan dinamis dalam praktek sehari-hari. Hal ini diakui sebagai modalitas perawatan yang dapat diprediksi dengan tingkat keberhasilan klinis yang tinggi. Gigi tiruan cekat konvensional tidak lagi dianggap sebagai pilihan perawatan utama untuk menggantikan gigi yang hilang. Meskipun jumlah pasien yang meminta perawatan implan meningkat, namun dokter gigi yang menawarkan perawatan implan dalam praktek sehari-hari masih terbatas. International Team for Implantology (ITI) atau tim implantologi internasional mendeskripsikan kasus straightforward sebagai kasus sederhana. Dinyatakan bahwa penempatan implan dilakukan pada jaringan lunak dan keras yang memadai, dan restorasi gigi tunggal di zona non-estetika. Tinjauan pustaka saat ini banyak membahas tentang penerapan implan kedokteran gigi di perguruan tinggi seluruh dunia dan dimasukkan ke dalam kurikulum mereka untuk program sarjana maupun pascasarjana dalam bidang kedokteran gigi umum. Konsensus Eropa tentang pendidikan implan kedokteran gigi menyimpulkan bahwa sebaiknya pendidikan teknik bedah untuk penempatan implan kasus straightforward disertakan ke dalam kurikulum. Berbagai tingkat dan keterbatasan implan kedokteran gigi dan keterampilan terkait harus diajarkan dan ditentukan oleh para staf pengajar. Makalah ini bertujuan untuk meningkatkan kesadaran para praktisi kedokteran gigi dan lembaga terkait di Indonesia terhadap pergeseran paradigma perawatan dalam penatalaksanaan kehilangan gigi. Dengan demikian para praktisi akan dapat menyertakan implan kedokteran gigi dalam perencanaan dan perawatanpasien.
\end{abstract}

Key words: curriculum, general dentistry, implants, straightforward cases

\section{INTRODUCTION}

A dental implant is a biomedical device usually composed of an inert metal or metallic alloy that is placed within the osseous tissues. The implant restoration consists of components that attach the prosthesis to the implant. The therapeutic goal of implant therapy is to support restorations that replace a tooth or missing teeth so as to provide patient's comfort, function and esthetics. ${ }^{1}$ The use of dental implants results in a better quality of life compared with conventional treatments. ${ }^{2-4}$ Conventional fixed prostheses are no longer considered to be the first 
choice treatment for replacing a missing tooth. Given this paradigm shift, the numberofpatientsrequesting or receiving implant therapy has increased throughout the years. However, dental practitioners who offered implant therapy in their daily practice are still limited especially in Indonesia. Universities worldwide have been slow to adjust to these developments in the curricula at both undergraduate and postgraduate levels.

An update on dental endosseous implants by the ADA council on scientific affairs in 2004 reported that the published literature on dental implants has grown to more than 5000 publications. Numerous clinical trials, outcomes research and consensus reports concluded that implant therapy is considered to be a predictable treatment modality for replacing missing teeth with high clinical success rates and should be recommended and applied in general practice. ${ }^{5}$

\section{Straightforward dental implant}

A classification of surgical and restorative implant dentistry procedures has been proposed, initially by the International Team for Implantology (ITI) in 2003 and has been further developed, which organizes them in three categories: straightforward, advanced and complex. Placement of an implant in a non-aesthetic zone and in adequate soft and hard tissue conditions is a straightforward procedure. ${ }^{6}$ This procedure is mostly applied in single tooth restorations supported by implants in the posterior area. Figure $1 \mathrm{~A}-\mathrm{C}$ and $2 \mathrm{~A}-\mathrm{D}$ are examples of management of a straightforward case.

In Indonesia and some other developing countries, the most common missing teeth were molars. Dental caries followed by periodontal diseases were the leading cause of tooth loss. The Decayed Missing Filled Teeth (DMF-T) score is gradually increasing every decade and experienced more in the younger age group. Their incidence decreases as age increases. ${ }^{7-10}$ Most cases of treating missing molars with implant therapy are straightforward cases. From both a biological and an economical point of view, the single tooth replacement with an implant is the first choice in situations with no or minimally restored neighboring teeth compared with conventional bridgework. It is a simple and costeffective treatment thus rendering such treatment a standard of care procedure. Numerous literatures reported a very high survival rate, more than $90 \%$ with the follow up periods from 2 to 16 years. ${ }^{5,11,12}$
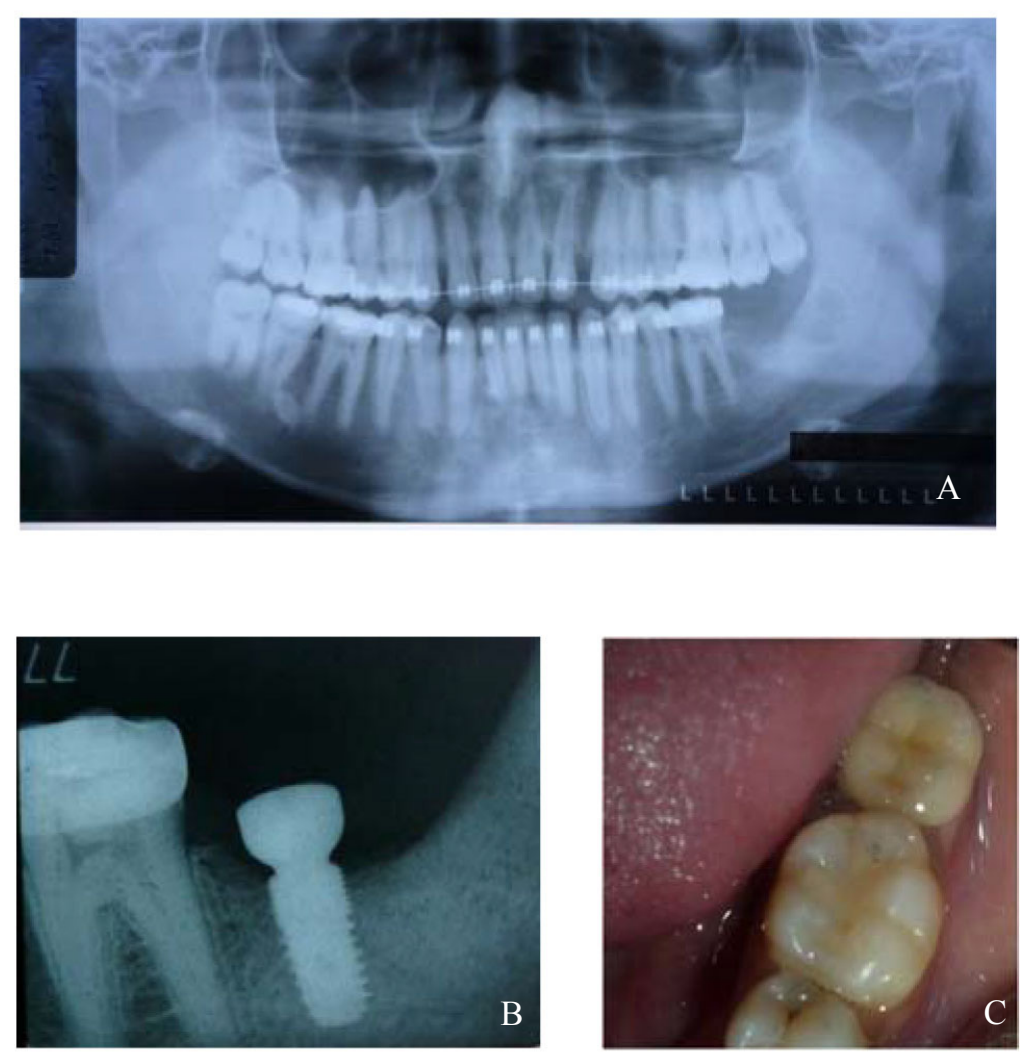

Figure 1A,B,C:Management of a straightforward dental implant case in site 37 

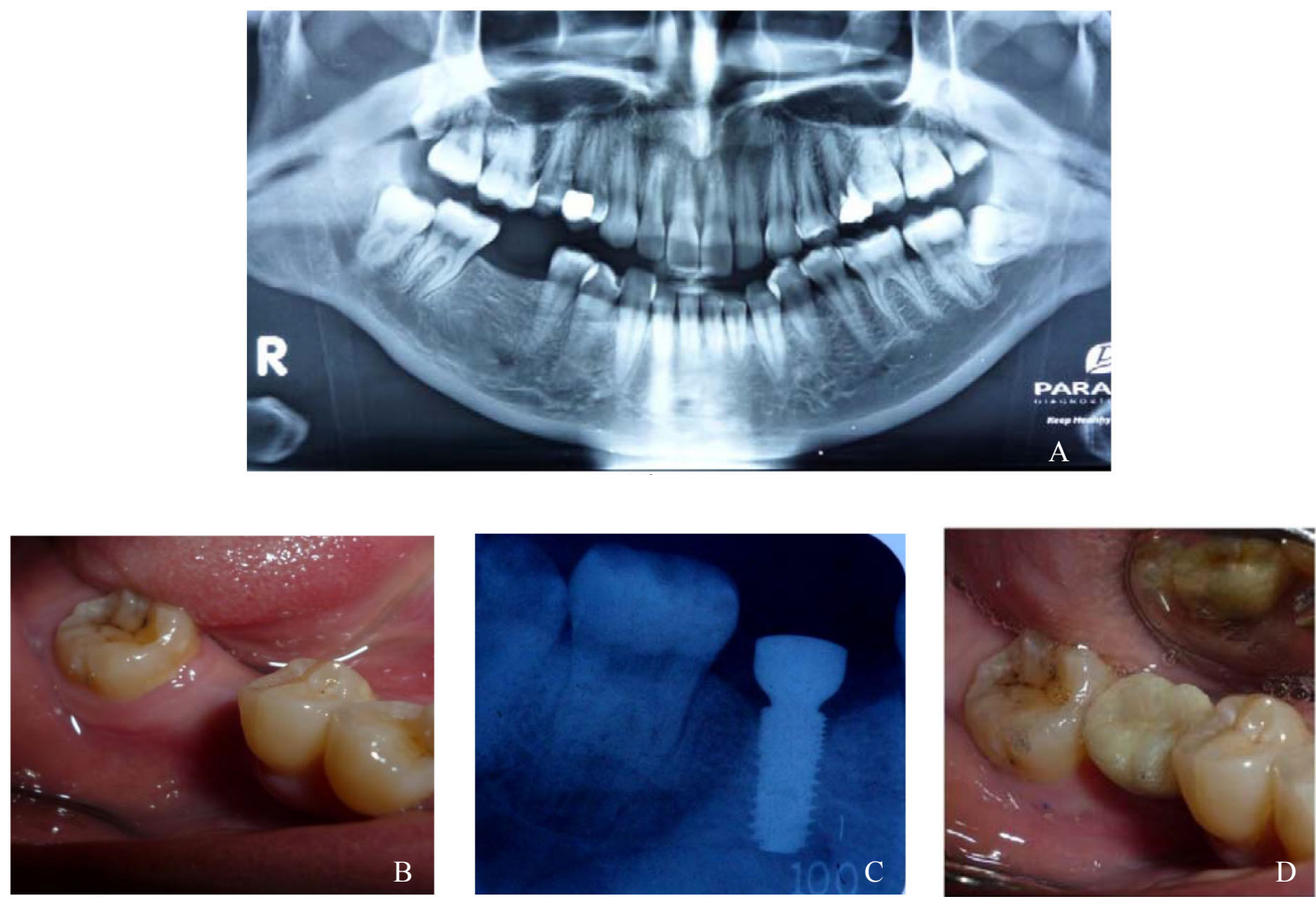

Figure 2A-D: Management of a straightforward dental implant case in site 46

\section{Dental implants in general dentistry}

Despite the increasing number of patients requesting implant treatments, there are only some clinicians who are offering implant therapy in their daily practice. Most dental schools all over the world have been slow in implementing the teaching of dental implant in general practice. As a result, it presents an extreme diversity in the spectrum of knowledge and competencies taught to the dental students among different universities or regions of the world. Consequently, general practitioners graduate with a very diverse amount of exposure to dental implant, while recent graduates or established dentists who want to introduce implant dentistry into their practice, turn to private bodies and institutions, professional groups or commercial sources for acquiring the necessary competencies.

General practitioners need to be educated to be able to include dental implants in the treatment planning of the patients and also undertake a significant part in the execution of such treatments. This can be achieved through two major developments: a revision of the undergraduate education and the development of targeted, quality assured and university driven postgraduate training. A new paradigm in undergraduate education is gradually being introduced worldwide, where students of dentistry will acquire certain important competencies within implant dentistry. This not only includes treatment planning and maintenance of implant patients, but also restoring straightforward implant cases, already as part of the undergraduate curriculum. ${ }^{13}$

A survey on undergraduate implant dentistry education in Europe confirms that implant dentistry is part of the undergraduate curriculum, although with a disparity in time. Whereas implant dentistry is an important part of clinical practice, coverage in the curriculum is limited and when compared with 10 years ago, even stagnating. Priorities within the curriculum should be evaluated depending on demands and treatment needs of the population. To optimize the education, learning guidelines should be developed, based on the expected competencies for practicing dentists. Undergraduate education may start the process that must continue through all levels of education, including the postgraduate level. ${ }^{14}$

A consensus meeting held by the Association for Dental Education in Europe (ADEE), there was widespread agreement among the academicians and implant-industry representatives about the urgent need to increase the penetration of implant dentistry 
within dental curricula. ${ }^{15,16}$ The following guidelines were proposed for implementation within European dental education; Future dentists should be able to incorporate oral implants into their overall treatment planning. They should understand the basic aspects of healing and tissue integration, basic biomechanical and material science principles, as well as surgical and prosthetic techniques. They should be prepared to continuously monitor the peri-implanttissue, render appropriate supportive therapy, and cope with biological and technical complications. The surgical technique for placing implants in straightforward cases should be included in the dental curriculum, while additional competence in the surgical phase should be required. The academic community should determine the levels and limitations to which the various aspects of implant dentistry and related skills are taught. Ethical and legal aspects of implant dentistry should not be forgotten. As part of implementing these guidelines, Ghent University, Belgium, recently expanded the final year of undergraduate clinical education to include the practice of placing of implants extra-orally in artificial bone, performance of hands on prosthetic procedures and flap creation and management using pig jaws. Because of time constraints, it was essential to choose straightforward cases and provide a prosthetic solution that was valid for all students and all cases. ${ }^{17}$

Oral Implantology has been included in the theoretical as well as in the clinical undergraduate dental curriculum since 1996 at the school of dentistry, Aarhus University, Denmark. Previous study reported that implant supported single tooth replacements performed by dental students as part of their undergraduate dental curriculum in Aarhus University were characterized by high survival rates (94\%) as well as few biological and technical complications. ${ }^{18}$

The academic community, representatives of implant dentistry, and health related institutions in Indonesia should be aware of these issues. Patient centered thinking provides an important argument for improving dental implant education. Whereas tooth loss can deeply affects patients' well being, even for patients who seem to adjust reasonably well to conventional dentures. In the future, it is essential for dentists, newly graduated and even established dental practitioners in Indonesia to understand the possibilities and limitations of implant dentistry. This includes not only patient selection, treatment planning and practical clinical implementation of the reconstructive therapy, but also appropriate responses to technical and/or biological complications.

\section{CONCLUSIONS}

There is no doubt that dental students should learn to incorporate the indication of dental implants in their overall treatment planning. Therefore, they will have to understand the basic aspects of healing and tissue integration, basic biomechanical and material science principles as well as surgical and prosthetic techniques. They will have to be able to monitor continuously the peri-implant tissues, render appropriate supportive therapy and cope with biological and technical complications.

While it is evident that the surgical procedure as such may require additional competence, the remainder of the aspects mentioned should be taught in the dental curriculum. This should include the attribution of responsibility for maintenance of implants and handling of biological and technical complications. Moreover, it is desirable to include the surgical technique for implant placement for straightforward cases into the dental curriculum. The levels and limitations to which the various aspects of implant dentistry and related skills are to be taught are determined by the academic community. Obviously, ethical and legal aspects of implant dentistry should not be forgotten.

\section{REFERENCES}

1. American Academy of Periodontology. Parameter on placement and management of the dental implant. J Periodontol. 2000;71:870-2.

2. Strassburger C, Kerschbaum T, Heydecke G. Influence of implant and conventional prostheses on satisfaction and quality of life: A literature review part 2: Qualitative analysis and evaluation of the studies. Int J Prosthodont. 2006;19:339-48.

3. McGrath C. Implants provide better health-related quality of life than conventional treatment for edentulous patients. Evidence-Based Dentistry. 2002;3:73-4

4. Serio FG. Implant supported/retained restorations: an integral part of contemporary dentistry. compendium of continuing education in dentistry 2011 June.

5. ADA Council on Scientific Affairs. Dental endosseous implants: an update. JADA. 2004;135:92-7.

6. Dawson A, Chen S. The SAC classification in implant dentistry. Berlin; Chicago: Quintessence Pub, 2009: 32.

7. Agtini MD. Percentage of artificial denture usage in Indonesia. Media Litbang Kesehatan. 2010;20:50-8.

8. Sanya BO, Ng'ang’a PM, Ng'ang’a RN. Causes and patterns of missing permanent teeth among Kenyans. East Afr Med J. 2004;81:322-5.

9. Demirci M, Tuncer S, Yuceokur AA. Prevalence of caries on individual tooth surfaces and its distribution by age and gender in University Clinic Patients. Eur J Dent. 2010;4:270-9.

10. Togoo RA, Yaseen SM, Zakirulla M, Al-Garni F, Khoraj AL, Meer A. Prevalence of fist permanent molar caries among 7-10 years old school going boys in Abha city, Saudi Arabia. J Int Oral Health. 
2011;3:29-34.

11. ADA Council on Scientific Affairs. Dental endosseous implants: an update. JADA. 2004;135:92-7.

12. Jeon H-R, Kim M-R, Lee D-H, Shin J-S, Kang N. Four-year survival rate of RBM surface internal connection non-submerged implants and the change of the peri-implant crestal bone. J Korean Assoc Maxillofac Plast Reconstr Surg. 2009;31:237-42.

13. Mattheos N. Implant Dentistry: A new specialty or an extension of general dentistry? AIM. 2010;1:21-5.

14. De Bruyn H, Koole S, Mattheos N, Lang NP. A survey on undergraduate implant dentistry education in Europe. Eur J Dent Educ. 2009;13:3-9.

15. Mattheos N, Albrektsson T, Buser D, De Bruyn H, Donos N, Hjørting Hansen E, et al; 1st European Consensus Workshop in Implant Dentistry
University Education. Teaching and assessment of implant dentistry in undergraduate and postgraduate education: a European consensus. Eur J Dent Educ. 2009;13:11-7.

16. Lang NP, De Bruyn H; 1st European consensus workshop in implant dentistry University Education. The rationale for the introduction of implant dentistry into the dental curriculum. Eur J Dent Educ. 2009;13:19-23.

17. De Bruyn H, Vandeweghe S. Increasing implant dentistry in undergraduate education using new technology: A pilot project. JIRD. 2010;2:40-5.

18. Bonde MJ, Stokholm R, Isidor F, Schou S. Outcome of implant supported single tooth replacements performed by dental students: A ten year clinical and radiographic retrospective study. Eur J Oral Implantol. 2010;3:37-46. 